Kaganga : Jurnal Pendidikan Sejarah dan Riset Sosial Humaniora.

Volume 1, Nomor 2, Desember 2018

e-ISSN : 2598-4934

$p-I S S N$ : 2621-119X

DOI : https://doi.org/10.31539/kaganga.v1i2.414

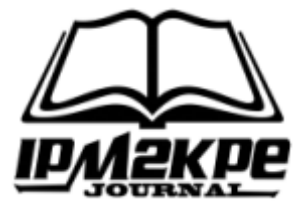

\title{
KELOMPOK LUDRUK CAK DURASIM (LUDRUK ORGANISATIE) DI SURABAYA TAHUN 1933-1945
}

\author{
Munifatuz Zuhriyyah \\ Universitas Airlangga Surabaya \\ munifatuz.zuhriyyah-2015@fib.unair.ac.id
}

\begin{abstract}
ABSTRAK
Tujuan penelitian ini untuk melihat perkembangan kelompok Ludruk Organisatie sebagai seni pertunjukan serta kiprahnya pada keadaan sosial di Surabaya. Kajian ini merupakan kajian historigrafi. Penyusunan historiografi harus ditempuh dengan menggunakan tahapan metode penelitian sejarah yang berupa heuristik, kritik sumber, interpretasi serta penyusunan historiografi sendiri. Hasil Penelitian, karakteristik yang dibawa oleh Ludruk Organisatie antara lain: pementasan ludruk tidak lagi masukkan unsur-unsur mistik; mengangkat simbol-simbol nasionalisme sebagai tema pertunjukan; serta kesenian ludruk pada masa ini dipentaskan secara komersil. Simpulan, kehadiran ludruk diterima dengan baik oleh masyarakat, khususnya di Jawa Timur sebagai hiburan sekaligus sebagai warisan budaya
\end{abstract}

Kata kunci: Cak Durasim, Ludruk Organisatie, Nasionalisme

\section{ABSTRACT}

The aim of the study was to look at the improvement of the group of Ludruk Organisatie as art performance as well as its role in the social circumstances in Surabaya. This study was a historiography study. The arrangement of historiography must be conducted through some steps of history study method such as heuristic, sources criticism, interpretation and historiography arrangement. The findings were the characteristic performed by Ludruk Organisatie such as 1) ludruk performance has no longer presented mystique elements; 2) presented nationalism symbols as the theme of the show; 3) it was presented commercially. In conclusion, the existence of ludruk was warmwelcomed by the society, especially in East Java as the entertainment as well as the heritage.

Keywords: Cak Durasim, Ludruk Organisatie, Nationalism 


\section{PENDAHULUAN}

Ludruk Organisatie atau LO merupakan salah satu nama kelompok ludruk di Surabaya. Pimpinan Ludruk Organisatie adalah Gondo Durasim yang akrab disapa Cak Durasim. Kelompok ludruk ini bukanlah generasi pertama dari kesenian ludruk. Pada Musyawarah Ludruk se-Jawa Timur yang berlangsung di Surabaya tanggal 21 - 28 Juni 1968, merumuskan bahwa masa awal ludruk di Jawa Timur dirintis oleh Pak Santik (Aribowo, Chistinawati, 2012).

Beliau adalah seorang petani asal Jombang yang juga bekerja sebagai pemain ludruk untuk mendapatkan penghasilan tambahan. Pada periode awal perkembangan ludruk, Kelompok Pak Santik lebih dikenal dengan kelompok ngamen dari pada kelompok kesenian ludruk. Hal ini disebabkan penampilan Pak Santik dan kawan-kawannya yang dikemas dalam bentuk ngamen yang diiringi beberapa alat musik.

Meskipun belum dikategorikan sebagai bagian dari kesenian teater, salah satu anggota dari kelompok Pak Santik telah memainkan peran menjadi sosok perempuan lengkap dengan semua atributnya (teledhek). Pak Santik merintis kelompok ludruknya sekitar tahun 1907, dengan menggandeng dua temannya, yakni Pak Amir dan Pak Pono. Ludruk pada masa Pak Santik disebut dengan Lerok. Ludruk kemudian berkembang di daerah-daerah lain seperti Malang, Mojokerto dan Surabaya.

Pada masa awal, kelompok ludruk melakukan pertunjukan untuk memenuhi undangan dalam sebuah hajatan pernikahan, khitan, maupun ngrawut dengan memasukkan unsurunsur magis dalam pementasannya. Kecenderungan tersebut, dalam perkembangannya, tidak lagi didapati pada LO bentukan Cak Durasim yang dalam pendiriannya bekerjasama dengan dr. Soetomo dan golongan priyayi baru yang tergabung dalam Persatoean Bangsa Indonesia (PBI).

Karakteristik yang dimunculkan oleh LO yakni mengusung tema-tema modern perkotaan. Berkat kerjasamanya dengan dr. Soetomo, kelompok ludruk ini tidak lagi melakukan pementasan di kampungkampung, namun lebih sering pentas di Gedung Nasional Indonesia (GNI) Surabaya. LO merepresentasikan kelompok ludruk yang mapan dan modern di pandangan masyarakat kampung, karena memiliki jadwal tersendiri yang teratur untuk melakukan pentas di GNI. Penghasilan yang mereka peroleh lebih banyak dibandingkan ketika melakukan pementasan di kampung. Penghasilan tersebut nantinya dibagi untuk anggota LO dan juga kepentingan PBI (Frederick, 1989).

Berkaitan dengan pernyataan yang telah penulis uraikan diatas, historiografi ini menyoroti sebuah kelompok kesenian ludruk yang memiliki karakteristik kompleks sebagai akibat dari aktivitas sosial dan politik dalam lingkungannya. Beberapa hal yang perlu digarisbawahi tentang Ludruk Organisatie adalah, bahwa kelompok ludruk ini merepresentasikan kesenian 
ludruk gaya baru dengan dikemas dalam bentuk sandiwara. Keadaan ini digambarkan sebagai pengaruh dari maraknya kemunculan kelompok sandiwara di Hindia Belanda.

Persoalan lainnya, bersamaan dengan periode kebangkitan nasional hingga masa pergerakan, masyarakat Hindia Belanda mulai sadar akan nasionalisme dan berusaha menyuarakan gagasan mengenai kebangsaan. Gerakan-gerakan nasionalisme pada masa awal digencarkan oleh kaum priyayi baru. Kaum priyayi baru mulai muncul pada awal abad ke-19. Golongan ini bukan hanya mereka yang berasal dari keturunan raja-raja Jawa, namun lebih kompleks daripada itu. Salah satu saluran yang melahirkan golongan ini adalah pendidikan, maka dapat dipahami bahwa priyayi baru terdiri atas kaum terpelajar (Frederick, 1989).

Pada perkembangan selanjutnya, kaum priyayi baru bekerjasama dengan kelompok ludruk yang berpotensi untuk mengenalkan nilainilai nasionalisme kepada masyakat kampung dan pinggiran kota. Ludruk Organisatie menjadi kelompok ludruk pertama yang memiliki peran ini.

Ludruk Organisatie dalam perkembangannya menginspirasi kelompok ludruk lainnya untuk menjadi pemain ludruk yang mapan dan modern serta mampu membawakan cerita-cerita progresif dan kritis. Kelompok ludruk lain kemudian mulai meninggalkan pementasan di kampung dan bercitacita melakukan pentas di GNI. Pada kurun waktu antara tahun 1930-1940- an merupakan salah satu periode perkembangan ludruk yang paling subur. Pada masa ini bermunculan kelompok ludruk baru oleh senimanseniman ludruk asal Jawa Timur. Lazimnya, kelompok-kelompok baru tersebut menamai perkumpulan ludruknya dengan nama pimpinan mereka, atau berdasarkan nama organisasi yang telah mereka sepakati bersama.

\section{METODE PENELITIAN}

Tujuan dari kajian ini adalah disusunnya sebuah historigrafi. Penyusunan historiografi harus ditempuh dengan menggunakan tahapan metode penelitian sejarah yang berupa heuristik, kritik sumber, interpretasi serta penyusunan historiografi sendiri. Bagian paling awal adalah mengumpulkan sumber. Langkah pertama yang ditempuh penulis yaitu mencari sumber-sumber terlulis, sumber cetak maupun noncetak lainnya yang memberikan informasi mengenai objek kajian dengan menggunakan metode penggunaan bahan dokumen (Kuntowijoyo, 1995).

Sumber-sumber yang terkumpul dibedakan dengan kategori memiliki kaitan secara langsung (sumber primer) dan tidak langsung (sumber sekunder). Penulis menemui kesulitan dalam menemukan sumber primer mengenai Ludruk Organisatie, sumber yang paling mendekati adalah berita dalam surat kabar dan majalah seperti Soeara Asia yang berupa artikel dengan judul "Tontonan Loedroek Doeloe dan Sekarang" oleh Iswojo, 
sumber ini ditemukan penulis di Perpustakaan Medayu, Surabaya; penulis juga menelusuri berita dalam surat kabar melalui situs Delpher, hasilnya berupa artikel dalam Swara Oemoem edisi 16 Juli 1936 dan 13 November 1942; Soeara Indonesia edisi 19 Januari 1931; serta Soeloeh Ra'jat Indonesia edisi 19 Juli 1931. Sumber lainnya adalah pidato sambutan dari dr. Soetomo pada Kongres keempat Persatoean Bangsa Indonesia atau disingkat dengan PBI (Paul W. Van Der Veur, 1981).

Sumber yang berhubungan tidak langsung adalah beberapa pasal dalam verslaag yang menggambarkan keadaan Kota Surabaya pada tahun 1930-an sampai dengan 1940-an. Sumber yang merupakan arsip pemerintah tersebut cukup membantu, mengingat batasan tempat serta tahun yang telah disebutkan adalah lingkup spasial dan sebagian lingkup temporal yang digunakan penulis. Sumber sekunder lainnya diperoleh penulis dari berbagai buku serta tinjauan pustaka terdahulu mengenai ludruk dan tokoh Cak Durasim yang memberikan kontribusi besar terhadap tulisan ini.

Informasi yang diperoleh dapat mewakili pendapat sejarawansejarawan dalam mempresentasikan Ludruk Organisatie, terutama dalam perspektif politik pada masa itu. Beberapa buku tersebut diantaranya Pandangan dan Gejolak: Masyarakat Kota dan Lahirnya Revolusi Indonesia (Surabaya 1926-1946) karya William H. Frederick dan Ritus Modernisasi: Aspek Sosial dan Simbolik teater
Rakyat Indonesia karya James L. Peacock. Kedua buku tersebut memberikan gambaran gamblang mengenai keadaan kota Surabaya serta perkembangan seni ludruknya dengan dipautkan ideologi dan keadaan politik, serta sedikit gambaran tentang LO dan tokoh Cak Durasim.

Tahap selanjutnya adalah kritik sumber, proses ini merupakan langkah untuk menguji kebenaran sumber. Tahap ini diperlukan untuk menghindari kesalahan penyusunan historiografi yang berupa ahistoris dan/atau anakronis. Kritik sumber yang dilakukan adalah kritik intern dan kritik ekstern. Setelah melalui pengujian dan analisis, maka fakta sejarah yang diperoleh disintesiskan melalui eksplanasi sejarah (T. Ibrahim Alfian, 1985). Tahap terakhir yaitu penyusunan historiografi dengan mengikuti aturan-aturan penulisan dan memperhatikan aspek kronologis suatu peristiwa.

\section{HASIL DAN PEMBAHASAN}

\section{Surabaya pada Awal Abad ke-20}

Awal abad ke-20 di seluruh wilayah Hindia Belanda, pemerintah kolonial sedang menjalankan program yang dinamai dengan politik etis yang telah disampaikan oleh Ratu Belanda pada tahun 1901. Kebijakan ini tentu tidak lepas dari usulan Mr. C. Th. Van Deventer, terkenal dengan aktikelnya pada majalah De Gids pada tahun 1899. Dampak dari kebijakan politik etis yang paling terlihat adalah munculnya sekolah-sekolah sebagai sarana pendidikan yang diperuntukkan anak-anak pribumi. Meski demikian, 
kemajuan pendidikan pada masa ini berjalan lambat. Fenomena ini terjadi hampir di seluruh wilayah Hindia Belanda, termasuk juga di Surabaya

Diilhami oleh kebijakan politik etis, kaum nasionalis Indonesia mulai sadar akan pentingnya gerakangerakan untuk memperjuangkan nasionalisme dan kemerdekaan Indonesia. Organisasi pertama yang diharapkan memenuhi ekspektasi ini adalah dengan dibentuknya Boedi Oetomo pada tahun 1908. Boedi Oetomo digagas oleh dr. Wahidin Soedirohoesodo dengan anggotanya para mahasiswa STOVIA serta ketua pertamanya yakni dr. Soetomo. Pada tahun 1924, diluar BO, dr. Soetomo kemudian membentuk sebuah studieclub yang baranggotakan kaum priyayi baru beraliran nasonalis.

Kelompok tersebut nantinya memiliki peranan aktif dalam menggali saluran-saluran nasionalisme lainnya di Surabaya. Menjadi fokus utama kelompok ini adalah saluran yang berasal dari masyarakat kampung di Surabaya (William H. Frederick, 1989).

Kelompok studieclub bentukan dr. Soetomo kemudian berganti nama menjadi PBI (Persatoean Bangsa Indonesia). Usaha-usaha yang dilakukan PBI dalam menggali saluran nasionalisme baru, telah berhasil membentuk dewan rakyat di tingkat kampung sebagai perwakilan masyarakat. Dewan rakyat tersebut dikenal dengan nama Sinoman Raad. Di sisi lain, dr. Soetomo juga berusaha untuk merangkul golongan seniman rakyat seperti pemain ludruk dan ketoprak. Menurutnya, pesan-pesan nasionalisme akan lebih efektif diterima oleh masyarakat kampung apabila disampaikan melalui kesenian milik masyarakat itu sendiri. dr Soetomo kemudian bekerjasama dengan seniman ludruk Cak Durasim, pimpinan Ludruk Organisatie (LO). Kerjasama kaum priyayi dengan ludruk terlihat dengan digelarnya pertunjukan ludruk di GNI, pun dapat dilihat dalam perubahan-perubahan karakteristik pada pementasan kesenian ini (Aryo Yudanto, 2009).

Surabaya sebagai pusat kegiatan perekonomian pada masa Hindia Belanda, menjadikan masyarakatnya mempunyai sikap terbuka dan heterogen. Kota dengan penduduk mayoritas berkebudayaan arek ini juga terbuka terhadap kesenian-kesenian baru yang masuk dan berkembang di Surabaya, mulai dari kesenian tradisional hingga modern. Kesenian tradisional yang berkembang di Surabaya antara lain meliputi ludruk, srimulat, ketoprak, dan seni jaranan. sedangkan kesenian modern yang turut berkembang di kota ini meliputi teater, sandiwara dan pertunjukan musik modern, serta film-film yang dipertontonkan di bioskop.

Pada masa ini, kota Surabaya merupakan tempat perkembangan teater dan sandiwara terbesar kedua di Indonesia setelah Jakarta (Fandy Hutari, 2009), serta menjadi salah satu pusat pemerintahan kolonial Hindia Belanda. Seiring dengan masa pergerakan, Ludruk Organisatie kemudian memasukkan pesan-pesan nasionalisme dalam pementasannya, 


$\begin{array}{lcr}\text { dengan } & \text { tujuan } & \text { mengedukasi } \\ \text { masyarakat } & \text { mengenai } & \text { semangat } \\ \text { nasionalisme } & \text { dan } & \text { perjuangan } \\ \text { kemerdekaan. } & & \\ & & \end{array}$

\section{Perkembangan Kesenian Ludruk di Surabaya}

Beberapa pendapat telah diajukan untuk merumuskan asal mula ludruk, kesenian teater tradisional khas Jawa Timur. Pendapat yang paling banyak digunakan adalah bahwa kesenian ludruk diturunkan dari jenis hiburan yang disebut lerok. Pernyataan ini juga diutarakan dalam Musyawarah ludruk se-Jawa Timur yang berlangsung di Surabaya pada tanggal 21-22 Juni 1968 (Aribowo, Christinawati, dkk, 2012).

Pada musyawarah tersebut dirumuskan bahwa ludruk berasal dari daerah Jombang, Jawa Timur. Pekembangan awal dari kesenian ludruk dipelopori oleh petani asal Jombang, Pak Santik. Ludruk pada masa Pak Santik disebut dengan lerok, pementasannya ditujukan untuk menghibur penonton dengan cara mengamen dengan diiringi musik. Perkembangan lerok selanjutnya, mendapatkan perhatian besar dari masyarakat serta kerap kali diundang di acara hajatan setempat. Pak Santik, dalam usaha awalnya itu telah mengajak dua temannya yakni Pak Pono yang memerankan badhut atau pelawak serta Pak Amir yang diharuskan berdandan seperti perempuan, tokoh ini dalam ludruk dinamakan teledhek (Henri Supriyanto, 1992).

Kesenian ludruk memiliki beberapa pemain dengan peran yang berbeda beda, seperti badhut yang dalam bahasa Jawa Kuno diartikan sebagai penari. Badhut dalam kelompok ludruk memiliki peran sebagai pelawak atau pameran humor. Pemeran lainnya adalah teledhek atau andhong, yaitu istilah untuk penari laki-laki yang berperan sebagai wanita. Pementasan ludruk diiringi dengan alat musik berupa gamelan, ayak-ayak, ayak-samera dan cokro. Ludruk juga dipahami sebagai suatu karya seni yang lahir dari seniman tradisional, menggunakan redaksi pentas yang sederhana agar mudah dipahami, karena ditujukan untuk konsumsi semua lapisan masyarakat, terutama masyarakat kampung dan pedesaan.

Kesenian ludruk berkembang di beberapa daerah di Jawa Timur, seperti Surabaya, Malang, Mojokerto dan Jombang, dimainkan oleh sekelompok orang atau grup kesenian dengan diiringi alunan gamelan sebagai musiknya. Pementasan ludruk secara garis besar ditujukan sebagai media hiburan dan rekreasi bagi penontonnya. Pihak pemain ludruk menjadikan pementasan sebagai mata pencaharian untuk mengejar kebutuhgan finansial. Kelompok ludruk biasanya diundang untuk tampil di acara hajatan masyarakat pedesaan dan kampung seperti khitanan dan pernikahan.

Kegiatan mengundang kelompok ludruk ini oleh masyarakat 
disebut dengan istilah nanggap. Tampilan ludruk yang dibawakan meliputi cerita atau lakon bertemakan kehidupan sehari-hari serta ceritacerita kepahlawanan. Menjadi salah satu ciri teater kesenian ludruk apabila menyiratkan ekspresi kehidupan masyarakat yang juga mengisahkan keseharian masyarakat serta sejarah (Aribowo, Christinawati, dkk, 2012).

Kisah-kisah tentang kehidupan masyarakat berkaitan erat dengan nilai-nilai yang berlaku dalam masyarakat itu sendiri. Masyarakat yang dimaksud adalah tempat lahirnya kesenian ludruk, masyarakat kampung atau desa (Peacock, 1967). Pada lingkaran feodalisme, masyarakat ini disebut dengan kalangan bawah, dikarenakan mereka yang berada di luar lingkungan keraton. Cerita yang berkaitan dengan nilai-nilai tradisional menguatakan posisi ludruk sebagai salah satu simbol teater tradisional serta lekat dengan simbol nilai masyarakat bawah. Dapat diartikan bahwa ludruk merupakan produk serta ekspresi nilai moral yang berasal dari masyarakat bawah dan masyarakat tradisional.

Pada kisaran akhir abad ke-19, muncul suatu kelompok sandiwara di Surabaya. Kelompok ini dipelopori oleh August Mahieu, seorang IndoPerancis yang mengadakan Opera Barat dengan menggunakan bahasa Melayu. Kelompok sandiwara ini kemudian dinamai Komedi Stamboel. Pada perkembangan selanjutnya mulai bermunculan kelompok-kelompok sandiwara baru. Nampaknya hal ini diadopsi juga oleh kelompok kesenian ludruk dan memunculkan suatu periode perkembangan ludruk yang bernama Ludruk Stamboel (Fandy Hutari, 2009).

Hal yang tidak berubah dari kesenian ludruk adalah penggunaan Bahasa Jawa yang dibawakan dengan sederhana sehingga mudah dipahami penonton. Menurut John H. McGlynn (2006) dalam antologi drama, penggunaan bahasa yang dengan mudah dipahami sebanyak mungkin penonton merupakan faktor penting. Di sisi lain, pementasan ludruk tidak sekedar sebagai mata pencaharian, sebagian kelompok ludruk memanfaatkan pementasan untuk menyampaikan pesan-pesan tertentu yang diselipkan dalam drama maupun kidungan.

Ludruk berusaha menyampaikan pelajaran penting bagi masyarakat bawah tentang dinamika dan hakekat hidup. Cerita yang dibawakan oleh kelompok ludruk merupakan konflik antargenerasi, konflik antara keterikatan pada tradisi generasi tua, menyangkut kawin paksa dan keinginan generasi muda yang dibatasi (Geertz, 2000).

Sifat ludruk yang sedemikian luwes dengan masyarakat, terutama penonton, menjadikan ludruk banyak diincar sebagai media propaganda. Pada masa kolonial, beberapa cerita yang dibawakan ludruk juga mencakup kekuasaan dan juga kekuatan orang-orang Belanda di Indonesia. Lakon yang dimaninkan adalah perlawanan pribumi kepada orang Belanda karena penindasan. Pribumi memainkan lakon protagonis, 
dan sebaliknya, orang Belanda sebagai antagonis, namun di akhir cerita, kemenangan adalah milik orang Belanda karena ketidakseimbangan kekuatan persenjataan. Memasuki masa pendudukan Jepang, teater ludruk mendapatkan pengawasan ketat saat pementasan. Unsur-unsur propaganda yang menjadi tujuan besar pemerintah Jepang berusaha diselipkan dalam teater-teater yang berkembang di Indonesia, termasuk salah satunya adalah ludruk.

Hingga pada masa setelah kemerdekaan, ludruk tetap dijadikan media strategis untuk melancarkan propaganda, seperti kelompok ludruk marhaen dengan ideologi pemikiran yang disebarkannya ke masyarakat, serta beberapa kelompok ludruk lainnya yang menyuarakan pemikiranpemikiran komunis pada masa itu. Pemanfaatan ludruk sebagai media propaganda kelompok tertentu menyebabkan vakumnya ludruk pasca peristiwa Gestapu, karena pemerintah menangkap para pemain ludruk yang diduga bergabung dengan PKI, dan para pemain yang tersisa (baik dari golongan tertuduh ataupun bukan), tidak berani mengadakan pentas sama sekali.

Masa-masa sulit pemain ludruk pada masa Orde Baru mulai hilang ketika para TNI AD Dan VIII Brawijaya berusaha menghidupkan kembali pementasan-pementasan ludruk (Aribowo, Christinawati, dkk, 2012). Gerakan ini didukung oleh para seniman ludruk yang tidak terlibat dengan kegiatan PKI ataupun Lekra. Usaha ini juga dibahas dalam
Musyawarah Ludruk se-Jawa Timur, bahwasannya telah dirumuskan usahausaha untuk pembinaan serta pelestarian ludruk. Pada masa ini, ludruk kembali populer, namun dengan ditunggangi kepentingankepentingan politik.

\section{Sejarah Ludruk Organisatie}

Ludruk Organisatie atau LO didirikan pada tahun 1930-an. Menurut William H. Frederick (1989), budaya dalam Ludruk Organisatie telah dipengaruhi oleh pemikiran kaum priyayi di Surabaya. Kaum priyayi yang dimaksud adalah dr. Soetomo beserta kelompoknya, yaitu para aktivis studieclub. Sebelum bertemu dengan dr. Soetomo, Cak Durasim dikenal sebagai orang yang pandai melucu, ia memiliki peran sebagai badhut dalam pementasan ludruk di kelompoknya. Melalui perannya, ia menyampaikan kritikkritik sumbang terhadap pemerintahan kotapraja dan terhadap penjajahan Belanda pada umumnya. Kritik-kritik tersebut dibawakan dengan cara halus serta nuansa humor yang dikenal masyarakat, atau lelucon asli berdasarkan kebiasaan berbicara masyarakat kampung (Frederick, 1989).

Dr. Soetomo melihat Ludruk Organisatie sebagai peluang yang luar biasa untuk memadukan pesan-pesan nasionalisme dalam pementasan ludruk agar lebih mudah sampai kepada masyarakat, khususnya yang tinggal di kampung. Soetomo mencitacitakan adanya sikap nasionalisme dapat hadir di masyarakat di 
kampung-kampung. Jika program dari Kotapraja didominasi oleh orang Eropa, bangsawan pribumi dan masyarakat terpelajar, maka harus ada media lain yang menaungi masyarakat diluarnya. Oleh karena itu Soetomo mengambil jalan kerjasama dengan para seniman rakyat dan memanfaatkan kesenian yang berasal dari golongan masyarakat bawah seperti ludruk atau ketoprak untuk membina rakyat (Van Der Veur, 1981). Ludruk Organisatie yang telah mendapat dukungan dari kaum nasionalis di Surabaya, dr. Soetomo, menjadi lebih gencar menyuarakan kritik-kritiknya. Ketua Boedi Oetomo pertama ini menyatakan sikap mendukung ludruk karena kesamaan pemikiran dalam pergerakan sosial dan politik.

Perubahan pada ludruk pada masa ini juga tidak lepas dari maraknya kemunculan kelompokkelompok kesenian sandiwara pada akhir abad ke-19. Unsur-unsur yang diadopsi oleh ludruk antara lain pementasan ludruk dilakukan dengan model sandiwara (LO kemudian dikenal mempelopori jenis ludruk sandiwara), pertunjukan yang bersifat komersil, dan perkembangan terakhir adalah penggunaan naskah-naskah sebagai pemandu lakon yang dibawakan para pemain. Oleh karena itu, seperti halnya kelompok sandiwara, ludruk kemudian dikonsumsi atau ditonton oleh berbagai kalangan masyarakat, termasuk diantaranya oleh kaum elit perkotaan.

\section{Dinamika Ludruk Organisatie dan Gagasan Nasionalisme}

Kedekatan hubungan antara dr. Soetomo dan Cak Durasim salah satunya terlihat dari akses yang diberikan kepada Ludruk Organisatie untuk dapat melakukan pertunjukan di Gedung Nasional Indonesia. LO mulai melakukan pentas di GNI sekitar tahun 1929 (Iswojo, Suara Asia, 1943) dan berlangsung seterusnya secara rutin. Pada beberapa kesempatan, dalam pidato maupun dalam tulisan dr. Soetomo akan menyebut nama Cak Durasim sebagai sosok yang perlu diteladani semangat nasionalismenya. Salah satunya, dalam memperingati ulang tahun PBI (Persatoean Bangsa Indonesia) yang ke-7 pada pidatonya, dr. Soetomo menyampaikan bahwa PBI adalah milik semua masyarakat, seluruh lapisan tanpa terkecuali dapat bergabung di PBI asalkan mau berusaha untuk meninggikan derajat negaranya (merujuk pada usaha memperjuangkan kemerdekaan). Disampaikan pula sebagai contoh figur-figur masyarakat yang bisa bergabung dalam PBI, berikut terjemahan bebas dari naskah aslinya:

[...] P.B.I. harus untuk semua orang Indonesia, rendah dan tinggi (kelas sosialnya), miskin dan kaya, rakyat biasa dan bangsawan, asalkan mereka semua bekerja dan berusaha untuk meningkatkan penampilan dan posisi negara mereka dan orang-orang mereka. Pangeran Diponegoro misalnya, jika dia masih hidup tentu harus bergabung dalam PBI. Misalnya pula seorang bupati, yang mempunyai jabatan di 
Volksraad dan berani menuntut penghapusan sewa tanah, tentu memiliki hak untuk bergabung di PBI, dan bahkan seniman ludruk dari kampung (postenmaker, humoris) Doerasim layak mendapat tempat yang bagus di PBI karena ia menabur benih nasionalisme dengan kidungannya. (Soeloeh Ra'jat Indonesia, 19 Juli 1931)

Berpangkal dari kerjasama Cak Durasim dengan dr. Soetomo dan kaum priyayi, terdapat perbedaan yang besar antara pementasan ludruk di masa lalu dan masa pergerakan. Kidungan, lagu serta kata-kata yang dibawakan di masa ini mengandung pesan-pesan baru yang membangkitkan perasaan nasionalistis (Soeara Indonesia, 19 Januari 1931). Ludruk bukan saja menampilkan penderitaan rakyat, tapi di dalamnya juga mengandung cita-cita perjuangan rakyat (Aryo Yudanto, 2009).

Disamping kerjasama dengan kaum priyayi, latar belakang organisasi Cak Durasim memiliki peranan dalam konstruksi wajah baru kesenian ludruk dalam Ludruk Organisatie. Berdasarkan hasil wawancaranya dengan alm. Oey Hay Djoen, Aryo Yudanto menyampaikan bahwa Cak Durasim merupakan anggota PKI illegal yang bergerak dari bawah tanah pasca kegagalan pemberontakan fisik 1926. Cak Durasim juga tergabung dalam kelompok yang menggalang Front Anti-Fasis pada kedatangan Musso di Indonesia pada tahun 1935. Maka menjadi relevan apabila Cak Durasim menata pertunjukan ludruknya bukan sekedar hiburan, tetapi juga memasukkan simbol-simbol perjuangan yang terlihat dari tema pementasan, nama tokoh, kostum, hingga kidungan serta pasemonpasemon yang dibawakan pemain. Beberapa tema yang diangkat dalam pementasan misalnya Sarip Tambaksoyo, Untung Surapati, Cak Sakera, hingga menyisipkan Markai yang merupakan tokoh PKI (Aryo Yudanto, 2009).

Perkembangan ludruk di Surabaya tidak selalu mulus, namun juga mengalami fluktuasi. Eksistensi ludruk di Surabaya pernah menyurut ketika ksenian ketoprak mulai masuk ke Surabaya. Kesenian ketoprak berasal dari Jawa Tengah, lahir di lingkungan keraton serta dipertunjukkan pada kalangan terbatas. Hiburan yang dikategorikan sebagai kesenian istana tersebut juga mengalami perubahan menyesuaikan dengan perkembangan zaman, maka pementasan ketoprak mulai dihadirkan kepada masyarakat umum pada awal abad ke-20. Kesenian ketoprak masuk ke Surabaya sekitar tahun 1931 dengan menggunakan model pertunjukan secara komersil.

Surabaya, pertunjukan ludruk tak terkecuali Ludruk Organisatie yang terkenal itu, kemudian harus bersaing dengan pendatang baru, yakni ketoprak. Kedatangan ketoprak dengan cerita khas keraton mendapat perhatian besar dari masyarakat dan kemudian diusulkan untuk melakukan pentas di GNI ketika ludruk tidak dijadwalkan. Persaingan antara ludruk 
dengan ketoprak tidak berlangsung lama, namun pernah mengalami tingkat paling sengit hingga memaksa LO melakukan pementasan gratis di kampung-kampung untuk menunjukkan bahwa kesenian ludruk masih ada (Frederick, 1989). Ludruk kemudian mendapatkan massa penontonnya lagi sekitar tahun 1936 (Iswojo, Suara Asia, 1943).

\section{Pentas dan Aturan Pemerintah}

Pada masa pergerakan, pesanpesan nasionalisme dalam pentas tidak hanya disuarakan oleh kelompok ludruk, namun juga oleh kelompok seni pertunjukan lainnya seperti ketoprak serta kesenian sandiwara modern. Penulis tidak berhasil menemukan informasi tentang kebijakan-kebijakan yang mengatur pagelaran seni pertunjukan dan sandiwara pada masa Hindia Belanda, serta apakah seni pertunjukan dikendalikan secara ketat oleh pemerintah kolonial. Namun di Jakarta, terdapat suatu informasi yang perlu ditelusuri lebih lanjut, tentang kebijakan dari Residen Batavia (pada bulan April 1900 sampai Maret 1902) yang melarang pertunjukan wayang di Jakarta dengan alasan mencegah meluasnya perjudian di kalangan orang-orang Islam

Penulis mengasumsikan bahwa pada masa ini tidak ada upaya pemerintah untuk mengendalikan seni pertunjukan dan sandiwara panggung, terbukti dengan bebasnya para seniman melakukan pertunjukan di Surabaya dan daerah lainnya. Keberlangsungan seni pertunjukan pada masa Hindia Belanda tentu sangat berbeda apabila dibandingkan dengan masa seletahnya, yakni masa pendudukan Jepang.

Kedatangan Jepang merubah hampir semua lini kehidupan masyarakat Indonesia. Aturan-aturan baru yang di buat oleh Jepang memaksa masyarakat untuk menyesuaikan diri jika tidak ingin menjadi lawan pemerintah. Salah satu kebijakan pemerintah Jepang adalah seperangkat aturan untuk mengawasi seni pertunjukan baik teater tradisional seperti ludruk, ketoprak, lenong, maupun teater yang lebih modern. Perkembangan drama di Indonesia yang mulai merangkak pada masa Belanda, kemudian berubah arah ketika pemerintah Jepang menguasai Indonesia dan menentukan dengan tegas bahwa segala jenis seni, tak terkecuali pertunjukan, harus digunakan sebagai media propaganda untuk mendukung gagasan Asia Timr Raya (John H. McGlynn, dkk, 2006). Sebagai antithesis dari aturan yang mengekang, kebijakan Jepang ini sekaligus merupakan masa menguntungkan bagi dokumentasi drama, karena sebelum melakukan pentas, pemerintah mewajibkan semua kelompok teater untuk menyerahkan naskah drama untuk disensor (John H. McGlynn, dkk, 2006).

Usaha pemerintah Jepang dalam kontrol dan propaganda adalah dengan membentuk suatu departemen khusus bernama Sendenbu (Departemen Propaganda) yang dibentuk dalam pemerintahan militer atau Gunseikanbu (Aiko Kurasawa, 2015). 
Pemerintah militer, sejak awal telah mengembangkan jaringan propaganda ke pelosok-pelosok desa dengan mengirimkan staf propaganda ke kotakota besar seperti Jakarta, Bandung, Yogyakarta, Semarang dan Surabaya. Pada perkembangan selanjutnya, setelah dibentuk Sendenbu, pemerintah juga membentuk badan propaganda lokal yang disebut Unit Operasi Distrik (Chiho Kosakutai).

Pada masa awal, propaganda Jepang lebih gencar pada film dan muatannya, hingga kemudian ahli bidang propaganda Jepang menyadari bahwa propaganda melalui senimanseniman modern di Indonesia kurang efektif, karena kaum seniman modern hanya dikenal dalam lingkungan terbatas kaum terpelajar saja. Propaganda untuk rakyat umum harus dilakukan melalui seniman-seniman pedesaan, seperti wayang, ketoprak, ludruk, maupun sandiwara Sunda. Namun kebanyakan dari teater tradisional adalah sandiwara lisan yang dilakukan dengan spontan tanpa naskah lakon, sehingga Jepang sulit mengontrol dan melakukan sensor (Jakob Sumardjo dalam Fandy Hutari, 2009). Menaggapi hal ini, pada April 1943, dibentukalah sebuah organisasi benama Keimin Bunka Shidosho atau Poesat Keboedajaan yang ditujukan untuk menjangkau dan mengawasi kesenian tradisional masyarakat.

Menurut Iswojo (Suara Asia, 1943), ludruk hanyalah pertunjukan yang ditujukan untuk masyarakat dengan pendidikan rendah. Ludruk disajikan dengan konsep yang bebas, tidak ada keteraturan yang mengikat dalam pertunjukannya. Dapat dikatakan bahwa pelaku ludruk memainkan rol atau alur seenaknya, jauh berbeda dengan pertunjukan wayang orang yang segala sesuatunya harus dilakukan menurut aturan-aturan yang pasti atau tetap. Namun pada masa pendudukan, semua jenis petunjukan, termasuk salah satunya kesenian ludruk, terikat dengan aturan-aturan yang telah ditetapkan oleh pemerintah Jepang.

Pada masa pendudukan Jepang, perkumpulan politik yang biasa diadakan di GNI dilarang berjalan. Pemanfaatan GNI masa Jepang hanya digunakan sebatas pertemuan dan aktivitas kesenian, termasuk disana menjadi panggung pertunjukan Ludruk Organisatie (Arsip GNI: Pahlawan Pergerakan Nasional dr. Soetomo). Sendenbu pada 19 Januari 1943 mengeluarakan beberapa peraturan dan kebijakan sensor untuk mengawasi jalannya kegiatan seni sandiwara di Jawa dan khususnya Jakarta. Peraturan ini berlaku untuk semua jenis sandiwara modern sekaligus sandiwara tradisional seperti ludruk. Dalam konteks Ludruk Organisatie pesan-pesan nasionalisme yang disampaikan tidak lagi gencar seperti masa pergerakan. Konsekuensi berupa hukuman berat apabila melanggar aturan menjadi hal yang perlu dipertimbangkan para pemain ludruk untuk mengambil jalan ekstrem tersebut.

Sejak awal keberadaan ludruk memang dekat dengan persoalanpersoalan keseharian masyarakat, baik cerita yang disampaikan maupun 
bahasa penyampaian. Maka analisis selanjutnya, ludruk sangat fleksibel jika digunakan sebagai alat untuk menyuarakan gagasan masyarakat kepada pemerintah, demikian sebaliknya, fleksibel pula dijadikan sebagai alat propaganda pemerintah untuk mensosialisasikan kebijakan kepada rakyat. Propaganda melalui media kesenian ludruk sangat memungkinkan terjadi dengan pertimbangan bahwa pentas seperti ludruk dapat dengan mudah hadir di tengah-tengah masyarakat. Pementasan ludruk dapat dikatakan selalu memikat penonton dalam jumlah banyak serta memiliki kepampuan komunikasi yang luwes dengan masyarakat karena disajikan dalam bahasa daerah. Perkembangan ludruk di Malang pada tahun 1920-an disajikan oleh pemainnya sebagai media untuk mengkritik. Melalui pantun yang didendangkan, berisi sindiran-sindiran yang ditujukan untuk mengomentari keamanan desa sampai dengan kritik untuk para lintah darat (Henri Supriyanto, 1992).

\section{SIMPULAN}

Kehadiran ludruk diterima dengan baik oleh masyarakat, khususnya di Jawa Timur sebagai hiburan sekaligus sebagai warisan budaya. Ludruk kemudian mengalami perubahan beriringan dengan masa pergerakan. Perubahan tersebut dipelopori oleh Kelompok Ludruk Cak Durasim atau Ludruk Organisatie. Pada masa ini pertunjukan ludruk dinilai lebih modern, ditandai dengan pementasan ludruk yang mulai dikomersilkan. Diawali oleh Ludruk Organisatie, untuk pertama kalinya pementasan ludruk digelar di GNI (Gedung Nasional Indonesia) dengan penonton dari semua lapisan masyarakat kota yang lebih kompleks dibandingkan masyarakat kampung. Perubahan tersebut merupakan buah dari kerjasama antara Cak Durasim dengan kaum priyayi nasionalis di Surabaya, salah satunya adalah dr. Soetomo. Menjadi ciri baru dalam pementasan Ludruk Organisatie adalah terdapat kidungan yang sarat akan pesan-pesan nasionalisme. Kesenian ludruk selanjutnya menjadi salah satu saluran perjuangan kemerdekaan pada masa pergerakan.

Perubahan yang dibawa oleh Ludruk Organisatie menandai perkembangan seni pertunjukan menuju modernisasi, yang nantinya memunculkan beberapa respon dari masyarakat sebagai penikmat seni. Pada kaum nasionalis, kesenian ludruk dianggap mengalami kemajuan dengan gagasan nasionalismenya. Penampilan ludruk juga dapat menarik massa lebih besar dari sebelumnya, yakni masyarakat perkotaan, masyarakat kampung dan pinggiran kota, kaum priyayi serta kaum elit perkotaan lainnya. Di lain sisi, sebagian masyarakat kampung kurang mendukung perubahan tersebut, menurut mereka ludruk tidak lagi cocok dimainkan di kalangan mereka, karena pementasan ludruk mengusung wawasan di luar tataran masyarakat kampung. Masyarakat kampung juga membenci kerjasama yang terjalin 
dengan kaum priyayi, sehingga menjadikan kelompok ludruk identik dengan kaum priyayi itu sendiri. Maka timbul dualisme sikap masyarakat atas perubahan pada Ludruk Organisatie, sebagaimana sikap mereka terhadap fenomena kaum priyayi baru.

\section{DAFTAR PUSTAKA}

Alfian, T., I. (1985). Sejarah dan Permasalahan Masa Kini. Yogyakarta: Universitas Gadjah Mada

Aribowo, C. (2012). Ludruk dan Reyog sebagai Sarana Penguatan Nilai Karakter Bangsa dan Perkembangan Ekonomi Tradisional. Jogjakarta: Ar-Ruzz Media

Een Uitdaging Voorkwam tot Debat of Polemiek. (1936, 16 Juli). Swara Oemoem, nr. 62

Foto's van het Loedroeg Gezelschap van Doerasim. (1942, 13 November). Swara Oemoem, nrs. 125

Frederick, W., H. (1989). Pandangan dan Gejolak: Masyarakat Kota dan Lahirnya Revolusi Indonesia (Surabaya 19261946). Jakarta: PT. Gramedia

Geertz, C. (2000). Negara Teater: Kerajaan-Kerajaan di Bali Abad Kesembilan Belas. Yogyakarta: Yayasan Bintang Budaya (terjemahan oleh Hartono Hadikusumo)

Hutari, F. (2009). Sandiwara dan Perang: Politisasi terhadap Aktivitas Sandiwara Modern masa Jepang di Jakarta 19421945. Yogyakarta: Ombak

Installantieplechtigheid op Nieuwe Partij "Persatoean Bangsa Indonesia" te Soerabaja. (1931,
19 Januari). Soeara Indonesia, nrs. 5-6

Iswojo. (1943). Tontonan Loedroek Doeloe dan Sekarang. Suara Asia

Kuntowijoyo. (1995). Pengantar Ilmu Sejarah. Yogyakarta: Yayasan Bentang Budaya

Kurasawa, A. (2015). Kuasa Jepang di Jawa: Perubahan Sosial di Pedesaan 1942-1945. Depok: Komunitas Bambu

McGlynn, J., H. (2006). Antologi Drama Jilid 2:1931-1945. Jakarta :Amanah Lontar

Peacock, J., L. (1967). Anti-Dutch, Anti-Muslim Drama Among Surabaja Proletarians: A Description of Performances and Responses, Southeast Asia Program Publications at Cornell University, Indonesia, No. 4

Supriyanto, H. (1992). Lakon Ludruk Jawa Timur. Jakarta: PT. Gramedia Widiasarana Indonesia

Supriyanto, H., (1989). Pertumbuhan dan Perkembangan Teater ludruk di Jawa Timur. Surabaya: Departemen Pendidikan dan Kebudayaan Provinsi Jawa Timur

Van der Veur, Paul W. (1981). $d r$. Soetomo: Pandangan dan Citacita untuk Bangsanya. Surabaya: Airlangga University Press

Yudanto, A. (2009). Politik Kebudayaan Lekra Surabaya: Aktivitas dan KArya Lembaga Kebudajaan Rakjat-LEKRA Surabaya tahun 1952-1959 (Skripsi). Diperoleh dari repository.unair.ac.id 